\title{
Status Kesehatan Remaja Perempuan yang Mengalami Perkawinan Anak
}

\author{
Muliani Ratnaningsih ${ }^{1}$, Rahayu Utami ${ }^{2}$, Fajar Waksi ${ }^{3}$ \\ ${ }^{1}$ Universitas Pejuang Republik Indonesia (UPRI), Jalan Gunung Bawakaraeng No.146 Makassar \\ ${ }^{2,3}$ Aliansi Remaja Independen (ARI) Sulawesi Selatan, Jalan Adhyaksa V No. 16 Makassar \\ Korespondensi: ${ }^{1}$ muli4ni.r@gmail.com ${ }^{2}$ rahayuutami17@gmail.com, $\underline{\text { 3fajarwaksi@gmail.com }}$
}

Submisi: 20 Agustus 2019; Revisi: 2 April 2020; Penerimaan: 3 April 2020

\begin{abstract}
Background: Indonesia was one of ten countries with the highest child marriage rate, and second highest in ASEAN after Cambodia. According to data, South Sulawesi was province with the 4th position contributing to the marriage of children in Indonesia. In South Sulawesi, age of marriage less than 14 years is 0.5 percent, while age of marriage between 15 years to 19 years is 33.5 percent.

Objective: This research aimed to know health status of adolescent girls who have conducted child marriage in Makassar City.

Method: This research used descriptive research with quantitative approach. The variables in this research health status from child and mother. The population in this study were all girls aged 15-24 years that chosed by Snowball Sampling nonrandom method with sample size 101 girls.

Results and Discussion: Health status in this study form mother and child. For mother, Body Mass Index (BMI) category owned by adolescent girls who experience child marriages, underweight 18 people (17.8\%), ideal body weight 66 people (65.3\%), and overweight 17 people (16.8\%). For child, the status of the weight of the first child at birth, low birth weight (LBW) 8 people (9.9\%), not experience LBW 73 people (90.1\%).

Conclusion: The description of the health status of adolescent girls shows some things that are not good for the health of adolescent girls that can be reviewed in terms of two things, namely the condition of the mother and the condition of the child. The most influential health conditions are the nutritional status of children, immunization of children, nutritional status of mothers, and some knowledge about reproductive health that is still low.
\end{abstract}

Keywords: children; health; marriage; status.

\section{ABSTRAK}

Latar Belakang: Indonesia adalah satu dari sepuluh negara dengan tingkat pernikahan anak tertinggi, dan tertinggi kedua di ASEAN setelah Kamboja. Menurut data, Sulawesi Selatan adalah provinsi dengan posisi ke 4 berkontribusi pada perkawinan anak-anak di Indonesia. Di Sulawesi Selatan, usia pernikahan kurang dari 14 tahun adalah 0,5 persen, sedangkan usia pernikahan antara 15 tahun hingga 19 tahun adalah 33,5 persen. Tujuan: Penelitian ini bertujuan untuk mengetahui status kesehatan remaja putri yang telah melakukan pernikahan anak di Kota Makassar.

Metode: Penelitian ini menggunakan penelitian deskriptif dengan pendekatan kuantitatif. Variabel dalam penelitian ini status kesehatan dari anak dan ibu. Populasi dalam penelitian ini adalah semua anak perempuan berusia 15-24 tahun yang dipilih dengan metode Snowball Sampling nonrandom dengan ukuran sampel 101 anak perempuan.

Hasil dan Pembahasan Status kesehatan dalam penelitian ini membentuk ibu dan anak. Untuk ibu, kategori Indeks Massa Tubuh (IMT) dimiliki oleh remaja putri yang mengalami pernikahan anak, berat badan 18 orang $(17,8 \%)$, berat badan ideal 66 orang $(65,3 \%)$, dan kelebihan berat badan 17 orang $(16,8 \%)$. Untuk anak-anak, status berat anak pertama saat lahir, berat badan lahir rendah (BBLR) 8 orang $(9,9 \%)$, tidak mengalami BBLR 73 orang $(90,1 \%)$.

Kesimpulan: Gambaran status kesehatan remaja putri menunjukkan beberapa hal yang tidak baik untuk kesehatan remaja perempuan yang dapat ditinjau dari segi dua hal, yaitu kondisi ibu dan kondisi anak. Kondisi kesehatan yang paling berpengaruh adalah status gizi anak, imunisasi anak, status gizi ibu, dan beberapa pengetahuan tentang kesehatan reproduksi yang masih rendah.

Kata kunci: Anak-anak; Kesehatan; Perkawinan; Status. 


\section{PENDAHULUAN}

Menurut UU Perkawinan Tahun 1974, pernikahan ialah ikatan lahir dan batin seorang pria dengan seorang wanita sebagai suami dan istri dengan tujuan membentuk keluarga (rumah tangga) yang bahagia dan kekal berdasarkan Ketuhanan Yang Maha Esa. Pernikahan adalah sah, apabila dilakukan menurut hukum masing-masing agamanya dan kepercayaannya itu. Indonesia merupakan salah satu dari sepuluh negara di dunia dengan angka pernikahan anak tertinggi, dan kedua tertinggi di ASEAN setelah Kamboja. ${ }^{1}$ Hal ini menunjukkan prevalensi pernikahan anak mengalami pergeseran prevalensi, terutama di daerah perkotaan.

Pada sebuah hasil penelitian terlihat bahwa secara umum sekitar separuh wanita di Indonesia menikah di usia muda. Walaupun trend pernikahan dini terus menurun, namun hingga periode 20102015 masih ditemui cukup tingginya persentase $(30,36 \%)$ wanita yang menikah dini di Indonesia. Fenomena menikah di usia muda juga masih sering dijumpai. Fenomena menikah di usia muda juga masih sering dijumpai pada masyarakat di Timur Tengah, Asia Selatan, dan Sub-Sahara Afrika. Di Asia selatan $48 \%$ menikah di bawah usia 18 tahun, Afrika 42\%, dan Amerika Latin 29\%. ${ }^{2}$

Membangun keluarga sejahtera dan berkualitas di mulai dengan suatu proses pernikahan yang sah menurut hukum, agama dan tidak melanggar hukum, agama dan tindak norma-norma kebiasaan yang berlaku dikalangan masyarakat. Pemerintah melalui BKKBN telah menetapkan usia pernikahan ideal agar dapat mewujudkan keluarga sejahtera dan berkualitas. Usia pernikahan ideal yaitu umur 21 tahun untuk perempuan dan umur 25 tahun untuk laki-laki.

Pada tahun 2012 di Indonesia, angka perempuan menikah usia 10-14 sebesar 4,2 persen, sementara perempuan menikah usia 15-19 tahun sebesar 41,8 persen. Pada tahun 2013 terjadi peningkatan rasio pernikahan muda pada daerah perkotaan, dibandingkan dengan daerah pedesaan. Adapun jumlah rasio kenaikan tersebut pada daerah perkotaan pada tahun 2012 adalah 26 dari 1.000 perkawinan, rasio itu naik pada tahun 2013 menjadi 32 per 1.000 pernikahan. Sedangkan pada daerah pedesaan yang menurun dari 72 per 1000 pernikahan menjadi 67 per 1000 pernikahan pada tahun 2013. ${ }^{3}$ Meskipun terjadi peningkatan jumlah rasio pernikahan di perkotaan, tetapi rasio angka pernikahan dini di daerah pedesaan masih lebih tinggi daripada perkotaan.

Permasalahan kesehatan reproduksi dimulai dengan adanya pernikahan dini yang hasilnya yaitu pada perempuan usia 10-54 tahun terdapat 2,6 persen menikah pada usia kurang dari 15 tahun kemudian 23,9 persen menikah pada usia 15-19 tahun. ${ }^{4}$ Di Sulawesi Selatan, usia menikah kurang dari 14 tahun adalah 0,5 persen, sedangkan usia menikah antara 15 tahun sampai 19 tahun adalah 33,5 persen. $^{3}$ Banyaknya kejadian pernikahan pada usia muda yaitu usia dibawah 19 tahun yang merupakan salah satu permasalahan yang berkaitan dengan sistem reproduksi pada remaja yang sangat memerlukan perhatian khusus.

Menurut data dari UNICEF, Sulawesi Selatan merupakan provinsi dengan posisi ke-4 memberikan kontribusi terhadap pernikahan anak di Indonesia. Kejadian pernikahan dini di daerah perkotaan di Indonesia yang masih tinggi, salah satunya adalah Kota Makassar. ${ }^{5}$ Usia perkawinan pertama tinggi pada usia di bawah dua puluh tahun di kota Makassar. Persentase perempuan yang menikah di bawah 21 tahun meningkat dari 3.22\% pada tahun 2015 menjadi $9.62 \%$ pada tahun 2016. Hal ini juga terjadi pada kelompok umur 16-18 tahun sekitar $21.77 \%$ dari $1.23 \%$ pada tahun sebelumnya. ${ }^{6}$ Berdasarkan latar belakang tersebut, Universitas Pejuang Republik Indonesia bekerja sama dengan Aliansi Remaja Independen (ARI) Sulawesi Selatan melakukan penelitian ini. Penelitian ini berfokus untuk mengetahui status kesehatan remaja perempuan yang telah melakukan pernikahan anak di Kota Makassar.

\section{METODE}

Penelitian ini dilaksanakan di 14 kecamatan Kota Makassar. Penelitian berlangsung selama 2 bulan Juli-Agustus 2017. Jumlah pertanyaan sebanyak 123 pertanyaan untuk melihat gambaran kesehatan remaja perempuan.

Penelitian ini merupakan penelitian deskriptif dengan kuantitatif dengan rancangan penelitian 
cross sectional study. Variabel dalam penelitian ini terbagi menjadi status kesehatan yang terdiri dari status kesehatan dari anak dan ibu (Kondisi anak: status gizi anak dan imunisasi anak; Kondisi ibu: kondisi saat hamil, kontrasepsi, gejala anemia, kondisi fisik, dan kondisi psikis).

Populasi dalam penelitian ini adalah seluruh remaja perempuan yang berusia 15-24 tahun. Sampel yang dipilih menggunakan cara nonrandom sehingga diperoleh jumlah sampel sebanyak 101 remaja perempuan berusia 15-24 tahun yang mengalami perkawinan anak.

Teknik penarikan sampel dalam penelitian ini dengan menggunakan metode nonrandom sampling yaitu teknik Snowball Sampling. Dalam penentuan sampel, pertama-tama dipilih 14 orang sampel setiap kecamatan, tetapi karena dengan 14 orang sampel ini belum merasa lengkap terhadap data yang diberikan sehingga para peneliti memutuskan menambah jumlah sampel menjadi 101 orang yang mewakili setiap wilayah kecamatan di Kota Makassar.

Analisis data dalam penelitian ini dilakukan dengan menggunakan analisis deskriptif. Penyajian datanya menggunakan tabel distribusi frekuensi yang menyajikan data jumlah dan persen. Selain itu, data persebaran jumlah remaja perempuan yang mengalami pernikahan anak disajikan dengan menggunakan peta.

\section{HASIL DAN PEMBAHASAN}

\section{Karakteristik Responden}

Data hasil penelitian selanjutnya disajikan dalam bentuk tabel. Data tersebut dianalisis dari 101 remaja perempuan yang mengalami pernikahan anak. Usia remaja perempuan yang diwawancarai. Usia terbanyak adalah usia 15-20 tahun sebanyak 62 orang $(61,4 \%)$, sedangkan usia $21-24$ tahun sebanyak 39 orang $(38,6 \%)$. Usia remaja perempuan saat pertama kali menikah tertinggi adalah usia 16 tahun sebanyak 68 orang $(67,3 \%)$, usia 15 tahun sebanyak 20 orang $(19,8 \%)$, dan usia 14 tahun sebanyak 13 orang (12,9\%). Tingkat pendidikan remaja perempuan. Tingkat pendidikan tertinggi adalah tamat SMP sebanyak 34 orang $(33,7 \%)$, sedangkan tingkat pendidikan terendah adalah tidak tamat SMA sebanyak 10 orang $(9,9 \%)$. Jenis pekerjaan remaja perempuan lebih banyak menjadi ibu rumah tangga sebanyak 94 orang (93\%), sedangkan remaja perempuan yang bekerja sebagai pegawai swasta merupakan pekerjaan terendah jumlahnya sebanyak 2 orang (2\%). Status kepemilikan rumah yang ditinggali oleh remaja perempuan: milik orang tua/keluarga sebanyak 78 orang $(77,2 \%)$, milik orang lain/kontrak/sewa sebanyak 13 orang (13\%), dan milik sendiri sebanyak 10 orang $(9,9 \%)$.

Selanjutnya, peta berikut ini menggambarkan persebaran pernikahan anak berdasarkan 14 kecamatan di Kota Makassar. Kecamtan Mariso sebanyak 8 orang $(7,9 \%)$, Kecamatan Mamajang sebanyak 9 orang $(8,9 \%)$, Kecamatan Tamalate sebanyak 7 orang $(6,9 \%)$, Kecamatan Rappocini 8 orang $(7,9 \%)$, Kecamatan Makassar sebanyak 8 orang $(7,9 \%)$, Kecamatan Ujung Pandang sebanyak 1 orang (1\%), Kecamatan Ujung Tanah 10 orang (9,9\%), Kecamatan Biringkanaya sebanyak 4 orang (4\%), Kecamatan Bontoala 5 orang (5\%), Kecamatan Manggala sebanyak 9 orang (8,9\%), Kecamatan Tallo sebanyak 13 orang $(12,9 \%)$, dan Kecamatan Tamalanrea sebanyak 4 orang (4\%). 


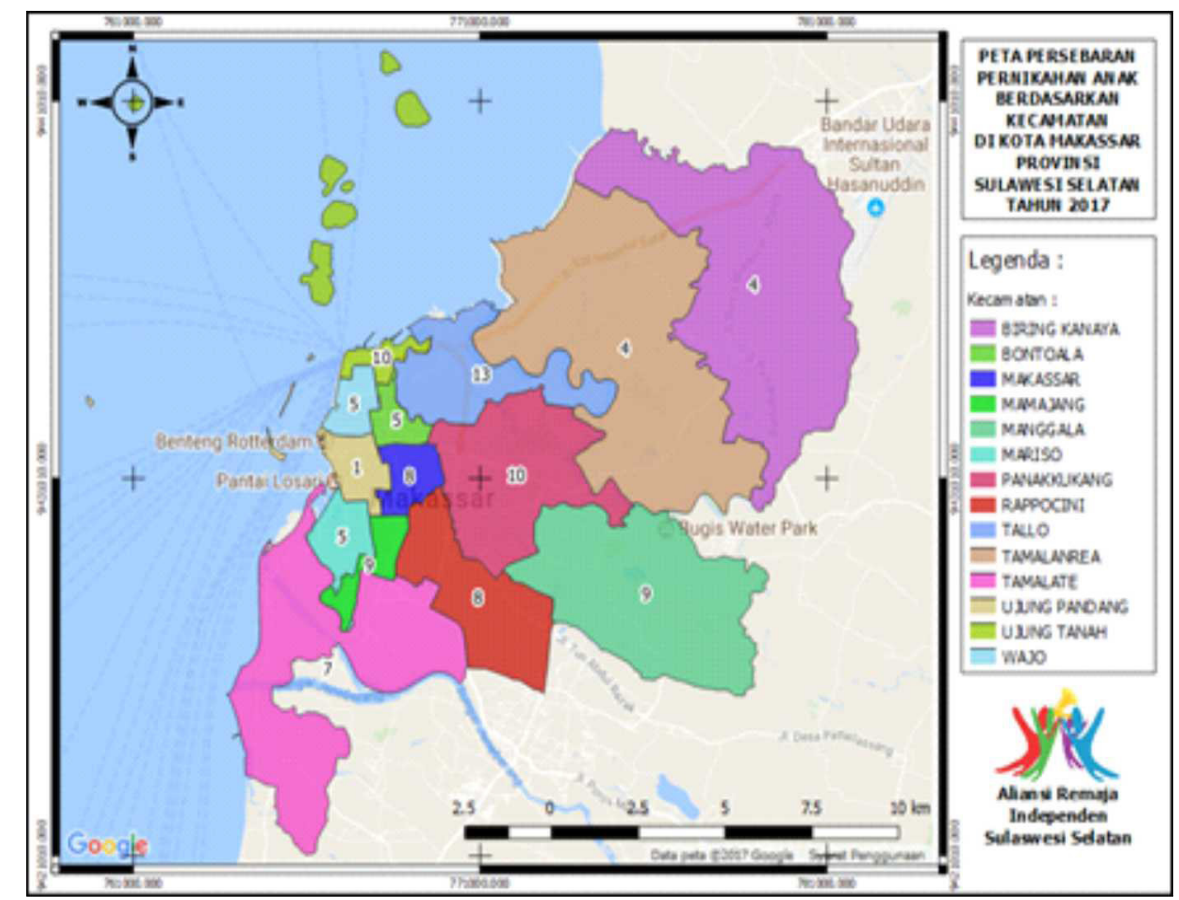

Gambar 1. Distribusi Responden berdasarkan Kecamatan

\section{Kondisi Ibu}

\section{Kondisi Saat Hamil}

Dari 101 jumlah responden remaja perempuan yang mengalami perkawinan anak, yang menyatakan pernah hamil sebanyak 92 orang $(91,1)$, belum pernah hamil sebanyak 8 orang $(7,9 \%)$, dan tidak bisa hamil sebanyak 1 orang (1\%). Selanjutnya, yang menyatakan hamil pada usia $\leq 16$ tahun sebanyak 74 orang $(80,5 \%)$, sedangkan $>16$ tahun sebanyak 18 orang $(19,5 \%)$.

Tabel 1. Distribusi Frekuensi Kondisi Kehamilan yang Pernah Dialami

\begin{tabular}{ccccccc}
\multirow{2}{*}{$\begin{array}{c}\text { Kondisi Kehamilan yang } \\
\text { Pernah Dialami }\end{array}$} & \multicolumn{2}{c}{$\begin{array}{c}\text { Seluruh } \\
\text { Kehamilan }\end{array}$} & \multicolumn{2}{c}{$\begin{array}{c}\text { Pengalaman } \\
\text { keguguran }\end{array}$} & \multicolumn{2}{c}{$\begin{array}{c}\text { Jumlah lahir } \\
\text { hidup }\end{array}$} \\
\cline { 2 - 7 } & $\mathrm{n}$ & $\%$ & $\mathrm{n}$ & $\%$ & $\mathrm{n}$ & $\%$ \\
\hline 1 kali & 54 & 58,7 & 5 & 5,4 & 51 & 55,4 \\
2 kali & 26 & 28,3 & 2 & 2,2 & 24 & 26,1 \\
3 kali & 12 & 13 & 0 & 0 & 6 & 6,5 \\
\hline
\end{tabular}

Tabel 1 menunjukkan kondisi kehamilan yang pernah dialami oleh remaja perempuan yang terdiri dari: jumlah seluruh kehamilan yang tertinggi yaitu 1 kali sebanyak 54 orang (58,7\%); jumlah mengalami keguguran tertinggi yaitu 1 kali sebanyak 5 orang $(5,4 \%)$; jumlah lahir hidup tertinggi yaitu 1 kali sebanyak 51 orang $(55,4 \%)$. 


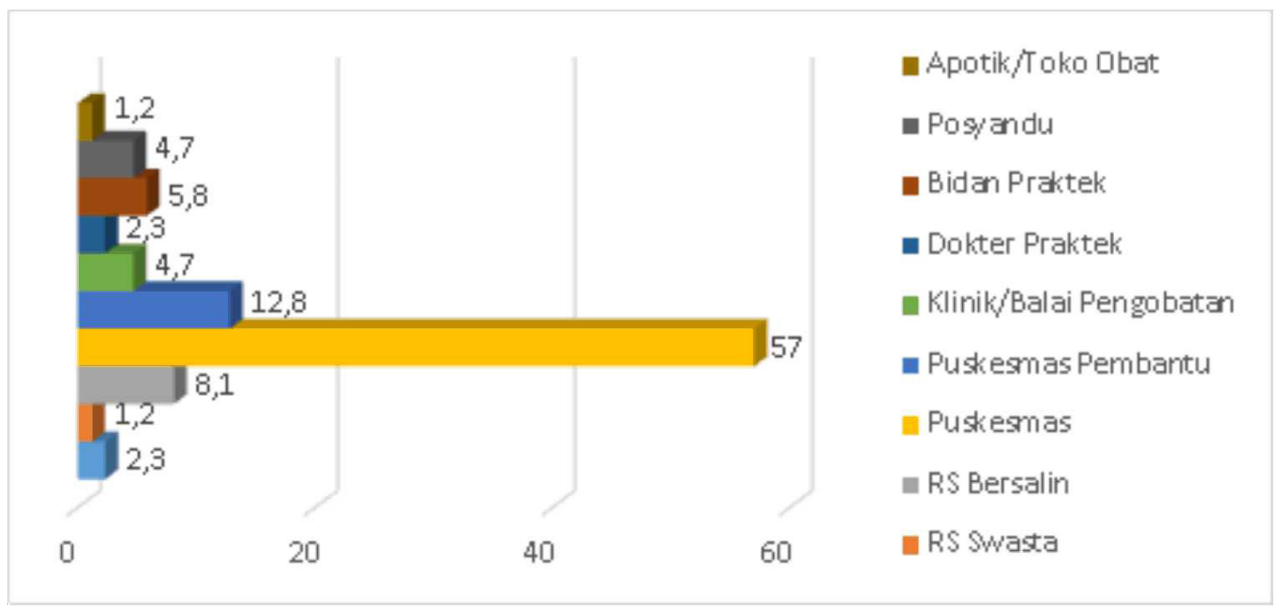

Gambar 2. Tempat Memeriksakan Kehamilan

Gambar 2 menyatakan bahwa dari 86 orang yang memeriksakan kehamilannya diberikan pertanyaan lanjutan mengenai tempat melakukan pemeriksaan kehamilan. Lokasi yang paling tinggi dikunjungi untuk persalinan adalah puskesmas sebanyak 49 orang
(57\%), sedangkan lokasi pemeriksaan kehamilan yang terendah untuk dikunjungi adalah RS swasta dan apotik/toko obat masing-masing sebanyak 1 orang $(1,2 \%)$.

Tabel 2. Distribusi Frekuensi Jenis Pemeriksaan Kehamilan

\begin{tabular}{|c|c|c|c|c|c|c|c|c|}
\hline \multirow{2}{*}{$\begin{array}{c}\text { Pemeriksaan yang } \\
\text { Dilakukan }\end{array}$} & \multicolumn{2}{|c|}{$\begin{array}{c}\text { Tekanan darah dan } \\
\text { tinggi badan }\end{array}$} & \multicolumn{2}{|c|}{$\begin{array}{c}\text { Berat badan dan } \\
\text { Tinggi badan }\end{array}$} & \multicolumn{2}{|c|}{$\begin{array}{c}\text { Berat badan, Tekanan } \\
\text { darah, Tablet Fe }\end{array}$} & \multicolumn{2}{|c|}{$\begin{array}{c}\text { Tinggi badan dan } \\
\text { usia kehamilan }\end{array}$} \\
\hline & $n$ & $\%$ & $n$ & $\%$ & $n$ & $\%$ & $\mathbf{n}$ & $\%$ \\
\hline Ya & 81 & 94,2 & 84 & 97,7 & 82 & 81,2 & 77 & 89,5 \\
\hline Tidak & 5 & 5,8 & 2 & 2,3 & 4 & 4,7 & 9 & 10,5 \\
\hline
\end{tabular}

Tabel 2 menunjukkan jenis pemeriksan kehamilan yang diperoleh oleh remaja perempuan di pusat kesehatan. Diukur tekanan darah dan tinggi badan ibu hamil sebanyak 81 orang $(94,2 \%)$; ditimbang berat bdan dan diukur ringgi badan ibu hamil sebanyak 84 orang (97,7\%); ditimbang berat badan, diukur tekanan darah, dan pemberian tablet zat besi sebanyak 82 orang $(81,2 \%)$; diukur tinggi badan dan mengetahui usia kehamilan sebanyak
77 orang $(89,5 \%)$. Selanjutnya, partisipasi suami yang menemani isrinya melakukan pemeriksaan kehamilan. Yang menemani sebanyak 38 orang $(41,3 \%)$, sedangkan yang tidak menemani sebanyak 54 orang $(58,7 \%)$. Kemudian, kebiasaan mengonsumsi tablet $\mathrm{Fe}$, yang mengonsumsi tablet Fe sebanyak 64 orang $(69,6 \%)$, hanya saja dari yang mengonsumsi tersebut hanya 7 orang yang mengonsumsi tablet Fe cukup selama kehamilan.

Tabel 3. Distribusi Frekuensi Kebiasaan Istirahat

\begin{tabular}{ccccc}
\multirow{2}{*}{ Kebiasaan Istirahat } & \multicolumn{2}{c}{ Cukup Tidur pada Malam Hari } & \multicolumn{2}{c}{ Tidur Siang pada Masa Kehamilan } \\
\cline { 2 - 5 } & $\mathrm{n}$ & $\%$ & $\mathrm{n}$ & $\%$ \\
Ya & 78 & 84,8 & 63 & 68,5 \\
Tidak & 14 & 15,2 & 29 & 31,5 \\
\hline
\end{tabular}

Tabel 3 menunjukkan kebiasaan istirahat remaja perempuan selama kehamilan, yang menyatakan cukup tidur pada malam hari sebanyak 78 orang
$(84,8 \%)$. Selanjutnya, yang melakukan kebiasaan istirahat/tidur pada siang hari sebanyak 63 orang (68,5\%). 
Tabel 4. Distribusi Frekuensi Kejadian Keguguran

\begin{tabular}{ccccc}
\multirow{2}{*}{ Kejadian Keguguran } & \multicolumn{2}{c}{ Perdarahan saat Kehamilan } & \multicolumn{2}{c}{ Pernah Mengalami Keguguran } \\
\cline { 2 - 5 } & $\mathrm{n}$ & $\%$ & $\mathrm{n}$ & $\%$ \\
Ya & 10 & 10,9 & 7 & 7,6 \\
Tidak & 82 & 89,1 & 85 & 92,4 \\
\hline
\end{tabular}

Tabel 4 menunjukkan distribusi kejadian keguguran, yang menyatakan pernah mengalami perdarahan saat kehamilan sebanyak 10 orang (10,9\%). Selanjutnya, yang pernah menyatakan pernah mengalami keguguran sebanyak 7 orang $(7,6 \%)$. Dari 7 orang yang mengalami keguguran tersebut, usia kehamilan saat keguguran tertinggi terjadi pada usia kehamilan < 20 minggu sebanyak 6 orang $(85,7 \%)$, sedangkan usia kehamilan $20-28$ minggu sebanyak 1 orang (14,3\%).

\section{Gejala Anemia}

Gejala Anemia yang ditanyakan kepada remaja perempuan pada penelitian ini adalah perasaan pusing (sakit kepala), merasa ingin jatuh pada saat berdiri, pandangan berkunang-kunang, merasa mual, merasa kurang bersemangat beraktivitas, telapak tangan tampak pucat, kelopak mata tampak pucat, wajah tampak pucat, ujung jari tampak pucat, merasa sesak nafas, detak jantung tidak beraturan, dan rambut rontok.

Tabel 5. Distribusi Frekuensi Gejala Anemia

\begin{tabular}{ccc} 
Gejala Anemia & $\mathrm{n}$ & $\%$ \\
Ya & 58 & 57,4 \\
Tidak & 43 & 42,6 \\
\hline
\end{tabular}

Tabel 5 menunjukkan gejala anemia yang dikategorikan berdasarkan jenis-jenis gejala anemia yang dirasakan oleh remaja perempuan tersebut. Yang mengalami anemia sebanyak 58 orang $(57,4 \%)$, sedangkan yang tidak mengalami sebanyak 43 orang $(42,6 \%)$.

\section{Kondisi Fisik}

Kondisi fisik yang dimaksudkan dalam penelitian ini adalah Indeks Massa Tubuh remaja perempuan, proses persalian yang pernah dijalani, hingga hubungan seksual. Untuk Indeks Massa Tubuh dilakukan pengukuran antropometri yaitu tinggi badan dan berat badan.

Tabel 6. Distribusi Frekuensi Indeks Massa Tubuh (IMT)

\begin{tabular}{lcc} 
IMT & $\mathrm{n}$ & $\%$ \\
Berat Badan Kurang & 18 & 17,8 \\
Berat Badan Ideal & 66 & 65,3 \\
Berat Badan Lebih & 17 & 16,8 \\
\hline
\end{tabular}

Tabel 6 menunjukkan kategori Indeks Massa Tubuh (IMT) yang dimiliki oleh remaja perempuan dalam penelitian ini, yaitu berat badan kurang sebanyak 18 orang $(17,8 \%)$, berat badan ideal sebanyak 66 orang $(65,3 \%)$, dan berat badan lebih sebanyak 17 orang $(16,8 \%)$.

Tabel 7. Distribusi Frekuensi Proses Persalinan

$\begin{array}{lcc}\text { Proses Persalinan } & \mathrm{n} & \% \\ \begin{array}{l}\text { Jenis Persalinan } \\ \quad \text { Normal }\end{array} & 76 & 75,2 \\ \quad \text { Operasi Sesar } & 16 & 15,8 \\ \quad \text { Belum pernah hamil } & 9 & 8,9 \\ \begin{array}{l}\text { Luka Persalinan (Sakit) } \\ \quad \text { Ya }\end{array} & & \\ \quad \text { Tidak } & 13 & 14,1 \\ \begin{array}{l}\text { Pernah Memeriksakan Luka } \\ \text { Persalinan }\end{array} & 79 & 85,8 \\ \quad \text { Ya } & & \\ \quad \text { Tidak } & & \\ \text { Pemeriksaan Terakhir } & 6 & 46,2 \\ \quad<1 \text { bulan lalu } & 7 & 53,8 \\ \quad 1-12 \text { bulan lalu } & & \\ \end{array}$

Tabel 7 menunjukkan proses persalinan yang pernah dialami oleh remaja perempuan. Yang melakukan persalinan normal sebanyak 76 orang $(75,2)$, sedangkan yang melakukan persalinan operasi sesar sebanyak 3 orang (3\%). Dari 79 orang yang sudah pernah menjalani proses persalinan ditanyakan kembali apakah luka saat proses persalinan masih sakit, yang menjawab masih 
sakit sebanyak 13 orang (16,5\%). Dari 13 orang yang merasakan masih sakit pada luka persalinan kemudian ditanyakan apakah pernah melakukan permeriksaan, yang pernah melakukan pemeriksaan sebanyak 6 orang $(46,2 \%)$. Selanjutnya, ditanyakan kapan pemeriksaan luka tersebut dilakukan yang menyatakan < 1 bulan lalu sebanyak 1 orang $(16,7 \%)$, sedangkan $1-12$ bulan lalu sebanyak 5 orang $(83,3 \%)$. Dari 6 orang tersebut ditanyakan kembali lokasi/tempat melakukan pemeriksaan luka proses persalianan yang menjawab rumah sakit dan puskesmas masing-masing sebanyak 2 orang (33,3\%), sedangkan yang menjawab posyandu/ tempat bidan/dokter praktek masing-masing sebanyak 1 orang $(16,7 \%)$. Selanjutnya, dari 7 orang yang tidak melakukan pemeriksaan luka proses persalinan ditanyakan kembali alasanya tidak melakukan konsultasi. Yang menyatakan bukan hal yang serius merupakan alasan terbanyak yang dilontarkan remaja perempuan sebanyak 5 orang $(71,4)$, sedangkan yang melontarkan alasan tidak ada biaya dan sibuk masing-masing sebanyak 1 orang $(14,3 \%)$.

Tabel 8. Distribusi Frekuensi Aktivitas Seksual

\begin{tabular}{lcc} 
Aktivitas Seksual & $\mathrm{n}$ & $\%$ \\
$\begin{array}{l}\text { Hubungan Seksual } \\
\quad \text { Ya }\end{array}$ & 82 & 81,2 \\
$\quad$ Tidak & 19 & 18,8 \\
$\begin{array}{l}\text { Frekuensi Hubungan Seksual } \\
\quad \text { < } 2 \text { kali/minggu }\end{array}$ & 60 & 73,1 \\
$\quad>2$ kali/minggu & 22 & 26,9 \\
Sakit pada saat Hubungan Seksual & & \\
$\quad$ Ya & 18 & 22 \\
$\quad$ Tidak & 64 & 78 \\
Masa Merasakan Sakit & & \\
$\quad \leq 3$ bulan & 10 & 55,6 \\
$\quad>3$ bulan & 8 & 44,4 \\
\hline
\end{tabular}

Tabel 8 menunjukkan distribusi frekuensi tentang aktivitas seksual. Yang menyatakan aktif melakukan hubungan seksual bersama pasangan sebanyak 82 orang $(81,2 \%)$. Frekuensi melakukan hubungan seksual $\leq 2 \mathrm{kali} /$ minggu sebanyak 60 orang, sedangkan $>2 \mathrm{kali} /$ minggu sebanyak 22 orang $(26,9 \%)$. Yang paling sering meminta pertama kali melakukan hubungan seksual adalah pasangan sebanyak 76 orang $(92,7 \%)$. Remaja perempuan yang merasakan sakit saat melakukan hubungan seksual sebanyak 18 orang (22\%) selanjutnya ditanyakan kembali sudah berapa lama merasakan sakit tersebut jawaban responden terbanyak adalah $\leq 3$ bulan sebanyak 10 orang (62,\%\%). Terakhir, dari 19 orang yang tidak lagi aktif melakukan hubungan seksual memiliki beberapa alasan, yaitu sudah bercerai dan tidak serumah masing-masing sebanyak 4 orang $(21,1 \%)$, sedangkan yang menyatakan alasan pasangan jarang berada di rumah sebanyak 11 orang (57,9\%).

\section{Kondisi Psikis}

Pada bagian ini ditanyakan kondisi psikis (kejiwaan) yang dialami oleh remaja putri, bagian ini diukur dengan menggunakan kuesioner DASS Depression Anxiety Stress Scales 42 pertanyaan. Kuesioner ini mencakup 3 kondisi psikis utama yaitu depresi, kecemasan, dan strees. Perhitungan kondisi psikis ini digunakan 0 = tidak pernah mengalami; 1 = Sesuai dengan yang dialami sampai tingkat tertentu, atau kadang-kadang; 2 = sering; 3 = Sangat sesuai dengan yang dialami, atau hampir setiap saat. Selanjutnya, dilakukan perhitungan total dari setiap bagian kondisi psikis yang dialami oleh remaja perempuan. Berikut ini adalah hasil analisis terhadap kondisi psikis anak perempuan yang mengaku telah diidentifikasi melaksanakan perkawinan anak.

Kondisi depresi dibagi menjadi 4 kategori skor. Tingkat normal (total skor 0-9); tingkat ringan (total skor 10-13); tingkat sedang (total skor 14-20); tingkat parah (total skor 21-27); dan tingkat sangat parah (total skor $\geq 28$ ). Kategori kecemasan dibagi menjadi 4 kategori skor. Tingkat normal (total skor 0-7); tingkat ringan (total skor 8-9); tingkat sedang (total skor 10-14); tingkat parah (total skor 15-19); dan tingkat sangat parah (total skor $\geq 20$ ). Kategori stress dibagi menjadi 4 kategori skor. Tingkat normal (total skor 0-14); tingkat ringan (total skor 15-18); tingkat sedang (total skor 19-25); tingkat parah (total skor 26-33); dan tingkat sangat parah (total skor $\geq 34$ ). 
Tabel 9. Distribusi Frekuensi Kondisi Psikis

\begin{tabular}{lcccccc}
\multicolumn{1}{c}{ Kondisi Psikis } & \multicolumn{2}{c}{ Depresi } & \multicolumn{2}{c}{ Kecemasan } & \multicolumn{2}{c}{ Stres } \\
& $\mathbf{n}$ & $\mathbf{\%}$ & $\mathbf{n}$ & $\mathbf{\%}$ & $\mathbf{n}$ & $\%$ \\
Normal & 76 & 75,2 & 41 & 40,6 & 71 & 70,3 \\
Ringan & 11 & 10,9 & 13 & 12,9 & 16 & 15,8 \\
Sedang & 11 & 10,9 & 29 & 28,7 & 10 & 9,9 \\
Parah & 3 & 3 & 12 & 11,9 & 4 & 4 \\
Sangat Parah & 0 & 0 & 6 & 5,9 & 0 & 0 \\
\hline
\end{tabular}

Tabel 9 menunjukkan kondisi psikis yang dialami oleh remaja perempuan. Mengalami depresi dengan kategori, yaitu ringan dan sedang masing-masing sebanyak 11 orang (10,9\%), sedangkan parah sebanyak 3 orang (3\%). Mengalami kecemasan dengan kategori, yaitu ringan sebanyak 13 orang $(12,9 \%)$, sedang sebanyak 29 orang $(28,7 \%)$, parah sebanyak 12 orang $(11,9 \%)$, bahkan sangat parah sebanyak 6 orang (5,9\%). Selanjutnya, mengalami stress dengan kategori, yaitu ringan sebanyak 16 orang $(15,8 \%)$, sedang sebanyak 10 orang $(9,9 \%)$, bahkan parah sebanyak 4 orang $(4 \%)$.

\section{Kondisi Anak}

Kondisi anak dalam penelitian ini dianalisis secara deskriptif. Kondisi anak ditanyakan pada remaja perempuan yang telah memiliki anak. Pada kondisi anak yang ditanyakan adalah status gizi anak, pemberian ASI (Air Susu Ibu), dan imunisasi anak.

\section{Status Gizi Anak}

Status gizi yang dimaksudkan ini adalah status gizi dasar pada anak yang dilahirkan oleh remaja perempuan yang menikah dibawah 18 tahun. Yang memiliki anak sebanyak 81 orang $(80,2 \%)$, yang tidak memiliki anak sebanyak 12 orang $(11,9 \%)$, dan masih dalam program kehamilan sebanyak 8 orang (7,9\%). Data usia pertama anak digunakan untuk mengklarifikasi usia perkawinan pertama yang dikatakan oleh responden sehingga bisa diketahui apakah responden benar-benar menikah pada usia tersebut. Usia anak pertama balita (0-5 tahun) sebanyak 68 orang (84\%), sedangkan usia kanakkanak (5-11 tahun) sebanyak 13 orang (16\%).

Tabel 10. Distribusi Frekuensi Status Gizi Anak

\begin{tabular}{lcc} 
Status Gizi Anak & $\mathbf{n}$ & $\%$ \\
\hline $\begin{array}{l}\text { Berat Badan Anak } \\
\quad \text { Berat Badan Lahir Rendah (BBLR) }\end{array}$ & 8 & 9,9 \\
$\quad$ Tidak Berat Badan Lahir Rendah & 73 & 90,1 \\
$\quad$ (BBLR) & & \\
Frekuensi Menimbang Anak 6 bulan & & \\
terakhir & 58 & 71,6 \\
$\quad$ Ya & 23 & 28,8 \\
$\quad$ Tidak & & \\
Lokasi Penimbangan Anak & & \\
$\quad$ Di rumah & 5 & 8,6 \\
Puskesma/Posyandu & 51 & 87,8 \\
Praktik bidan/dokter/perawat & 2 & 3,4 \\
\hline
\end{tabular}

Tabel 10 menunjukkan status gizi anak berdasarkan berat badan anak, frekuensi menimbang anak 6 bulan terakhir, dan lokasi penimbangan anak. Status berat badan anak pertama saat dilahirkan, yang mengalami berat badan lahir rendah (BBLR) sebanyak 8 orang $(9,9 \%)$, sedangkan yang tidak mengalami BBLR sebanyak 73 orang $(90,1 \%)$. Frekuensi menimbang anak dalam 6 bulan terakhir, yang menimbang sebanyak 58 orang $(71,6 \%)$, sedangkan yang tidak menimbang sebanyak 23 orang $(28,4 \%)$. Lokasi penimbangan anak banyak dilakukan di puskesmas/posyandu di sekitaran rumah sebanyak 51 orang $(87,9 \%)$, di rumah sebanyak 5 orang $(8,6 \%)$, dan terahir di praktik dokter/bidan/perawat sebanyak 2 orang $(3,4 \%)$. 


\section{Pemberian ASI (Air Susu Ibu)}

Tabel 11. Distribusi Frekuensi Pemberian ASI (Air Susu Ibu)

\begin{tabular}{lcc} 
Pemberian ASI (Air Susu Ibu) & $\mathbf{n}$ & $\%$ \\
\hline $\begin{array}{l}\text { Status Menyusui } \\
\quad \text { Masih menyusui }\end{array}$ & 37 & 45,7 \\
$\quad$ Tidak lagi menyusui & 44 & 54,3 \\
\hline Produksi ASI & & \\
$\quad$ Cukup & 36 & 97,3 \\
$\quad$ Tidak Cukup & 1 & 2,7 \\
\hline Pemberian ASI Eksklusif & & \\
$\quad$ Memberikan & 27 & 75 \\
$\quad$ Tidak memberikan & 9 & 25 \\
\hline Alasan Tidak Memberikan ASI & & \\
Eksklusif & & \\
$\quad$ Harus kembali bekerja & 1 & 11,1 \\
$\quad$ ASI tidak keluar & 4 & 44,4 \\
$\quad$ Takut bentuk payudara berubah & 1 & 11,1 \\
$\quad$ Hamil lagi & 2 & 22,2 \\
$\quad$ Susu formula lebih praktis & 1 & 11,1 \\
\hline
\end{tabular}

Tabel 11 menunjukkan pemberian ASI (Air Susu Ibu) berdasarkan status menyusui, produksi ASI, pemberian ASI Eksklusif dan alasan tidak memberikan ASI Eksklusif. Status menyusui, yang menyatakan masih menyusui hingga penelitian berlangsung sebanyak 37 orang $(45,7 \%)$, sedangkan yang sudah tidak lagi menyusui sebanyak 44 orang
(54,3\%). Produksi ASI, remaja perempuan yang menyatakan ASI-nya cukup untuk bayi sebanyak 36 orang $(97,3 \%)$, sedangkan yang menyatakan tidak cukup sebanyak 1 orang (2,7\%). Remaja perempuan yang memberikan bayinya ASI Eksklusif selama 6 bulan sebanyak 27 orang (75\%), sedangkan yang tidak memberikan sebanyak 9 orang (25\%). Alasan tidak memberikan ASI Eksklusif terbanyak dikarenakan remaja perempuan tersebut menyatakan ASI tidak keluar setelah melahirkan sebanyak 4 orang $(44,4 \%)$.

\section{Imunisasi Anak}

Imunisasi anak yang dimaksudkan dalam penelitian ini adalah status imunisasi anak pertama setelah perkawinan yang diberikan oleh petugas kesehatan kepada bayi/anak dari remaja perempuan tersebut. Dari 81 remaja yang memiliki anak, terdapat $77(95,1)$ remaja perempuan yang memberikan imunisasi kepada anaknya, sedangkan yang tidak memberikan imunisasi kepada anaknya sebanyak 4 orang (4,9\%).

Tabel 12 menunjukkan distribusi frekuensi imunisasi Hepatitis B-0 pada anak. Yang memberikan imunisasi sebanyak 67 orang (87\%). Selanjutnya, yang menjawab dengan benar usia pemberian imunisasi Hepatitis B-0 pada anak yaitu 0-24 jam dan $>24$ jam -7 hari sebanyak 52 orang $(77,6 \%)$.

Tabel 12. Distribusi Frekuensi Imunisasi Hepatitis B-0 dab BCG

\begin{tabular}{lcccc} 
& \multicolumn{2}{c}{ Hepatitis B-0 } & \multicolumn{2}{c}{ BCG } \\
\cline { 2 - 5 } \multicolumn{1}{c}{ Imunisasi } & $\mathbf{n}$ & $\%$ & $\mathbf{n}$ & $\%$ \\
Memberikan & & & & \\
$\quad$ Ya & 67 & 87 & 60 & 77,9 \\
$\quad$ Tidak & 5 & 6,5 & 3 & 3,9 \\
$\quad$ Tidak Tahu & 5 & 6,5 & 14 & 13,9 \\
\hline Usia saat imunisasi & & & & \\
0 - 24 jam & 34 & 50,7 & 13 & 21,7 \\
$\quad$ > 24 jam - 7 hari & 18 & 26,9 & 31 & 51,7 \\
$\quad$ Tidak tahu & 15 & 14,9 & 16 & 26,7 \\
\hline
\end{tabular}

Tabel 12 menunjukkan distribusi frekuensi imunisasi BCG pada anak. Yang memberikan imunisasi sebanyak 60 orang (77,9\%). Selanjutnya, yang menjawab dengan benar usia pemberian imunisasi BCG pada anak yaitu 0-29 hari dan $\geq 1$ bulan sebanyak 44 orang $(73,4 \%)$. 
Tabel 13. Distribusi Frekuensi Imunisasi Polio

\begin{tabular}{lcccc}
\multicolumn{1}{c}{ Imunisasi } & \multicolumn{2}{c}{ Polio } & \multicolumn{2}{c}{ DPT-HB Combo } \\
\cline { 2 - 5 } & $\mathbf{n}$ & $\%$ & $\mathbf{n}$ & $\%$ \\
\hline Memberikan & & & & \\
$\quad$ Ya & 59 & 76,6 & 54 & 70,1 \\
$\quad$ Tidak & 2 & 2,6 & 5 & 6,5 \\
$\quad$ Belum waktunya (umur $\leq 1$ bulan) & 2 & 2,6 & 2 & 2,6 \\
$\quad$ Tidak Tahu & 14 & 18,2 & 16 & 20,8 \\
\hline Usia saat imunisasi & & & & \\
Benar & 9 & 15,3 & 15 & 28,8 \\
Salah & 11 & 18,7 & 3 & 5,7 \\
Tidak tahu & 36 & 35,6 & 34 & 65,4 \\
\hline Frekuensi pemberian imunisasi & & & & \\
$\quad$ Benar & 9 & 15,3 & 8 & 33,3 \\
Salah & 11 & 18,7 & 16 & 66,7 \\
Tidak Tahu & 36 & 35,6 & 48 & 54,7 \\
\hline
\end{tabular}

Tabel 13 menunjukkan distribusi frekuensi imunisasi polio dan DPT-HB Combo pada anak. Yang memberikan imunisasi sebanyak 59 orang $(76,6 \%)$, sedangkan yang tidak tahu bahwa anaknya diberikan imunisasi polio sebanyak 14 orang $(18,2 \%)$. Selanjutnya, yang menjawab dengan benar usia pemberian imunisasi polio pada anak sebanyak 9 orang $(15,3 \%)$, sedangkan yang tidak tahu sebanyak 36 orang (35,6\%). Terakhir, yang menjawab frekuensi pemberian imunisasi polio pada anak yang benar sebanyak 9 orang (15,3\%), sedangkan yang tidak tahu sebanyak 36 orang (35,6\%). Untuk imunisasi DPT-HB Combo, yang menyatakan memberikan imunisasi sebanyak 54 orang (70,1\%), sedangkan yang tidak tahu anaknya diberikan imunisasi DPTHB Combo sebanyak 16 (20,8\%). Selanjutnya, yang menjawab dengan benar usia pemberian imunisasi DPT-HB Combo pada anak sebanyak 15 orang $(28,8 \%)$, sedangkan yang tidak tahu sebanyak 34 orang $(65,4 \%)$. Terakhir, frekuensi pemberian imunisasi DPT-HB Combo pada anak yang jawabanya benar sebanyak 8 orang $(33,3 \%)$, sedangkan yang tidak tahu sebanyak 48 orang $(54.7 \%)$.

Tabel 14. Distribusi Frekuensi Imunisasi Campak

\begin{tabular}{lcc} 
Pemberian Imunisasi Campak & $\mathrm{n}$ & $\%$ \\
Ya & 47 & 61 \\
Tidak & 5 & 6,5 \\
Belum waktunya (umur $\leq 9$ bulan) & 14 & 18,2 \\
Tidak Tahu & 11 & 14,3 \\
\hline
\end{tabular}

Tabel 14 menunjukkan status pemberian imunisasi campak pada anak. Yang memberikan imunisasi campak sebanyak 47 orang (61\%), yang tidak memberikan sebanyak 5 orang $(6,5 \%)$, belum waktunya (umur $\leq 9$ bulan) sebanyak 14 orang $(18,2 \%)$, dan tidak tahu sebanyak 11 orang $(14,3 \%)$.

Tabel 15. Distribusi Frekuensi Alasan Tidak Memberikan Imunisasi Pada Anak

\begin{tabular}{lll} 
Alasan Tidak Memberikan Imunisasi & $\mathrm{n}$ & $\%$ \\
Anak sering sakit & 2 & 50 \\
Tempat Imunisasi jauh & 1 & 25 \\
Sibuk/Repot & 1 & 25 \\
\hline
\end{tabular}

Tabel 15 menunjukkan alasan tidak memberikan imunisasi pada anak. Dari 4 orang yang tidak memberikan imunisasi kepada anaknya mengutarakan beberapa alasan berikut: anak sering sakit sebanyak 2 orang (50\%), tempat imunisasi jauh sebanyak 1 orang (25\%), dan sibuk/repot sebanyak 1 orang (25\%).

Pernikahan anak merupakan suatu pernikahan formal atau tidak formal yang dilakukan dibawah usia 18 tahun. ${ }^{2}$ Suatu ikatan yang dilakukan oleh seseorang yang masih dalam usia muda atau pubertas disebut pula pernikahan dini berpendapat bahwa pernikahan muda adalah pernikahan yang dilaksanakan di usia remaja. ${ }^{7}$ Dalam hal ini, yang dimaksud dengan remaja adalah antara usia 10-19 tahun dan belum kawin. 
Seseorang yang telah melakukan ikatan lahir batin antara pria dengan wanita sebagai seorang suami istri dengan tujuan membentuk keluarga, baik yang dilakukan secara hukum maupun secara adat/kepercayaan dapat dikatakan pula sebagai pernikahan. Apabila suatu pernikahan tersebut dilakukan oleh seseorang yang memiliki umur yang relatif muda maka hal itu dapat dikatakan dengan pernikahan anak. Umur yang relatif muda yang dimaksud tersebut adalah usia pubertas yaitu usia antara 10-19 tahun. Sehingga seorang remaja yang berusia antara 10-19 tahun yang telah melakukan ikatan lahir batin sebagai seorang suami istri dengan tujuan membentuk keluarga dikatakan sebagai pernikahan dini atau pernikahan telalu muda.

Salah satu faktor terjadinya pernikahan dini lainnya adalah pendidikan remaja dan pendidikan orang tua. Dalam kehidupan seseorang, cara menyikapi masalah ini dan membuat keputusan termasuk hal yang lebih kompleks ataupun kematangan psikososialnya sangat dipengaruhi oleh tingkat pendidikan seseorang. Tingkat pendidikan maupun pengetahuan anak yang rendah dapat menyebabkan adanya kecenderungan melakukan pernikahan anak. Hal ini sejalan dengan penelitian yang dilakukan di Bandung yang menunjukkan bahwa remaja muda yang berpendidikan rendah memiliki resiko (odds ratio) 4,259 kali untuk menikah daripada remaja muda yang berpendidikan tinggi. Remaja yang memiliki latar belakang pendidikan yang tinggi memiliki resiko lebih kecil untuk menikah dini dibandingkan dengan remaja yang memiliki latar pendidikan rendah. Tingkat pendidikan merupakan salah satu faktor yang mempengaruhi seseorang dalam menyikapi masalah dan membuat keputusan ataupun kematangan psikososialnya. ${ }^{8}$

Pada penelitian ini responden yang melaksanakan pernikahan anak tertinggi memiliki status pendidikan telah tamat SMP dan tamat SMA masing-masing sebanyak 27 orang $(26,7 \%)$ dan 28 orang $(27,7 \%)$. Penelitian ini sejalan dengan yang dilakukan oleh Budi Setyawati, dkk (2013) yang menunjukkan bahwa pada kelompok wanita menikah dini yang saat wawancara berusia $<30$ tahun tidak hanya berpendidikan SD. Akan tetapi, hampir separuhnya berpendidikan SMP/SMA. Hal ini dapat terjadi karena saat ini pendidikan dasar tidakah hanya sampai tingkat SD. Akan tetapi, telah sampai di tingkat SMP dan SMA. Pendidikan adalah salah satu faktor demografi yang penting. Saat tingkat pengetahuan berpengaruh pada kondisi sosial, ekonomi, dan kesehatan. ${ }^{9}$

Pada negara berkembang, orang tua menikahkan anaknya di usia dini salah satu faktor yang menyebabkannya adalah kemiskinan. Orang tua seringkali punya anggapan bahwa anak perempuan merupakan beban ekonomi keluarga. Dimana perkawinan anaknya dianggap merupakan usaha mempertahankan kehidupan keluarga. ${ }^{10}$ Hal senada juga ditemukan di Madura, di mana fenomena pernikahan dini di masyarakat madura salah satunya disebabkan alasan untuk mengurangi beban ekonomi keluarga selain rendahnya kesadaran tentang pentingnya pendidikan. Beban ekonomi keluarga berkurang dengan cara mendapatkan menantu yang akan menambah aset ekonomi penopang keluarga bertambah. ${ }^{11}$

Persoalan ekonomi keluarga, orang tua menganggap jika anak gadis yang melamar dan mengajak menikah, setidaknya ia diharapkan mampu dan tidak lagi bergantung kepada orang tua karena ada suami yang siap menafkahi. Sekalipun, usia anak perempuannya belum mencapai kematangan baik secara fisik dan mental. Sayangnya, para remaja perempuan ini menikahi pria yang berstatus ekonomi ta jauh beda dengannya, sehingga menimbulkan kemiskinan yang baru. Pernikahan dini terjadi karena keadaan keluarga yang hidup di bawah garis kemiskinan sehingga remaja menikah dengan pasangannya dianggap mampu meringankan beban orang tua. Kehidupan seseorang sangat didukung oleh kampuan ekonomi keluarga, sebuah keluarga yang berada di bawah garis kemiskinan akan sangat sulit unruk memebuhi kebutuhan dalam keluarga karena terdesak oleh kebutuhan ekonomi, dengan kemampuan ekonomi yang lemah apalagi di zaman sekarang kebutuhan terus meningkat, beban yang ditanggungpun terasa semakin berat. ${ }^{12}$

Pernikahan anak atau dini akan menyebabkan motivasi belajar yang dimiliki seseorang tersebut akan mulai mengendur karena banyaknya tugas yang harus mereka lakukan setelah mereka menikah. Dengan kata lain, pernikahan dini dapat menghambat terjadinya proses pendidikan dan pembelajaran. Dengan pola pendidikan yang tepat, kematangan seseorang sudah mulai terbentuk 
di usia belasan tahun. Sebaliknya, dengan pola pendidikan yang tidak taat atau belum tercapai, tingkat kematangan tidak akan terbentuk walaupun usia sudah melebih 25 tahun.

Rendahnya tingkat pendidikan remaja sering sekali berbanding lurus dengan tingkat status sosial ekonomi keluarga tentunya mempunyai peranan terhadap perkembangan anak, dengan perekonomian yang cukup maka anak-anak mereka mempunyai kesempatan yang luas, seperti mendapatkan pendidikan dan kebutuhan hidup anggota terpenuhi. Lain halnya dengan keadaan sosial ekonomi orang tua yang kurang mampu, anak-anak merak tidak mempunyai kesempatan untuk bersekolah yang lebih tinggi. Beban orang tua semakin berat untuk mencukupi kebutuhan anggota keluarga atau anak-anak mereka. Untuk mengurangi beban orang tua yang berasal dari ekonomi rendah maka mereka akan cepat-cepat menikahkan anak remajanya yang belum cukup umur.

Permasalahan lain yang ditemukan dalam penelitian ini sebagai salah satu penyebab pernikahan anak adalah beberapa oknum melakukan tindakan pelanggaran dengan mengubah usia anak perempuan yang akan dinikahkan seperti Kartu Tanda Penduduk (KTP) dan Kartu Keluarga (KK) sehingga anak tersebut dapat dinikahkan agar keluarganya yang menikahkan tidak terjerat hukum di kemudian hari.

Beberapa penelitian di Indonesia menunjukkan bahwa terkadang pernikahan di usia dini terjadi sebagai solusi untuk kehamilan yang terjadi di luar nikah. Menurut Sarono, pernikahan di usia dini banyak terjadi pada masa pubertas, hal ini terjadi karena remaja sangat rentang terhadap perilaku seksual yang membuat mereka melakukan aktivitas seksual sebelum menikah. Hal ini terjadi karena adanya kebebasan pergaulan antarjenis kelamin pada remaja, dengan mudah disaksikan dalam kehidupan sehari-hari dan juga karena adanya faktor dari media massa. ${ }^{7}$

Peran orang tua juga menentukan remaja untuk menjalani pernikahan anak. Orang tua juga memiliki peran yang besar untuk penundaan usia perkawinan anak. Hal ini sejalan dengan penelitian yang dilakukan di Malang yang mengungkapkan bahwa keputusan menikah di usia anak sangat ditentukan oleh peran oang tua. Peran orang tua sangat penting dalam membuat keputusan menikah. Hal ini merupakan keputusan yang terkait dengan latar belakang relasi yang terbangun antara orang tua dan anak dengan lingkungan pertemanannya. ${ }^{13}$

Pernikahan anak terjadi jika ditinjau dari sisi sosial dan kebudayaan adalah adanya dukungan orang tua yang ingin menikahkan anaknya. Jika remaja perempuan dan laki-laki tidak banyak kegiatan sehingga mereka hanya diberikan pilihan untuk menikah di usia dini dan meninggalkan bangku sekolah. Lingkungan masyarakat yang mengatakan perkawinan sebaiknya cepat-cepat jika tidak disegerakan akan mendapat cemooh dan julukan perawan tua atau tidak laku. Pengaruh adat kebiasaan yang menyakan jika anak gadisnya telah dewasa, tetapi belum berkeluarga akan dipandang aib bagi keluarga. ${ }^{14}$ Selain itu, terdapat dua alasan utama pernikahan dini yang merupakan strategi bertahan secara ekonomi. Pertama, tidak jarang banyak orang tua menikahkan anak perempuaanya atau menjodohkan dengan anak teman/ tetangganya supaya kehidupan ekonomi sang anak berubah. Kedua, alasan perlindungan untuk anak perempuannya karena menurut beberapa orang tua anak mereka akan terlindungi jika tidak dibiayai oleh orang tuanya. Bukankah hal ini malah boleh dikategorikan bahwa orang tua telah melakukan pemindahan tanggung jawab supaya mereka tidak lagi menanggung anak yang mereka nikahkan tersebut.

Dalam penelitian ini, ditemukan juga beberapa remaja yang mengaku menikah dibawah 16 tahun. Hal ini dilarang oleh UUD No. 1 Tahun 1974 tentang Perkawinan, tetapi terdapat oknum yang memang melakukan praktik ini. Oknum ini melakukan penggandaan dokumen kependudukan dengan cara menaikkan usia calon pengantin perempuan ataupun lelaki sesuai dengan batas usia minimal pernikahan yang telah ditetapkan oleh undang-undang sehingga oknum tersebut tidak dapat terjerat hukum.

Beberapa penelitian di Indonesia menunjukkan bahwa terkadang pernikahan di usia dini terjadi sebagai solusi untuk kehamilan yang terjadi di luar nikah. Hal ini sesuai dengan penelitian ini yang dinyatakan langsung oleh remaja perempuan tersebut bahwa karena ia hamil di luar nikah 
sehingga kedua belah pihak orang tua memberikan solusi itu saja.

Pernikahan anak di lingkungan remaja cenderung berdampak negatif baik dari segi sosial ekonomi, mental/psikologis, fisik, terutama bagi kesehatan reproduksi sang remaja tersebut. Perempuan muda yang sedang hamil, berdasarkan penelitian akan mengalami beberapa hal, seperti akan mengalami pendarahan, keguguran, dan persalinan yang lama atau sulit. ${ }^{(13)}$ Oleh karena itu, pernikahan anak memiliki banyak dampak negatif yang sangat penting untuk diketahui baik oleh remaja maupun orang tua.

Berkaitan dengan berat badan bayi lahir, bayi dikelompokkan berdasarkan berat lahirnya, yaitu bayi berat lahir rendah (BBLR), yaitu berat lahir $<2500$ gram. Dalam penelitian ini terjadi kelahiran bayi dengan BBLR. Hal inilah yang akan menjadi masalah di masa akan datang karena anak yang lahir dengan BBLR sangat memungkinkan akan mengalami stunting ataupun overweight.

Kondisi yang fatal dan mengancam jiwa akan dialami oleh 14,2 juta anak perempuan di seluruh dunia yang menjadi pengantin anak setiap tahunnya selama periode 2011-2020. Perkawinan usia anak menyebabkan kehamilan dan persalinan dini, yang berhubungan dengan angka kematian yang tinggi dan keadaan tidak normal bagi ibu karena tubuh anak perempuan belum sepenuhya matang untuk melahirkan. Anak perempuan usia 10-14 tahun memiliki resiko lima kali lebih besar untuk meningal dalam kasus kehamilan dan persalinan usia 20-24 tahun, dan secara global kematian yang disebabkan oleh kehamilan merupakan penyebab utama kematian anak perempuan usia 15-19 tahun. Anak perempuan menghadapi risiko tingkat komplikasi yang terkait dengan persalinan yang jauh lebih tinggi, seperti fistula obstetri, infeksi, pendarahan hebat, anemia dan eklampsia. Terdapat kajian yang menunjukkan bahwa perkawinan usia anak di Indonesia berhubungan dengan buruknya kesehatan reproduksi dan kurangnya kesadaran anak perempuan terhadap risiko persalinan dini.

Anemia pada ibu hamil bukan tampa resiko, menurut penelitian yang sebelumnya dilakukan tingginya angka kematian ibu berkaitan erat dengan anemia. Anemia juga menyebabkan rendahnya kemampuan jasmani karena sel-sel tubuh tidak cukup mendapat pasokan oksigen. Pada wanita hamil, anemia meningkat frekuensi komplikasi pada kehamilan dan persalinan. Resiko kematian maternal, angka prematuritas BBLR dang angka kematian perinatal meningkat.

Pelayanan kesehatan bayi termasuk salah satu dari beberapa indikator yang bisa menjadi ukuran keberhasilan upaya peningkatan kesehatan bayi dan balita. Pelayanan ini terdiri dari penimbangan berat badan, pemberian imunisasi dasar (BCG, DPT/HB1-3, polio 1-4, dan campak), Stimulasi Deteksi Intervensi Dini Tumbuh Kembang (SDIDTK) bayi, pemberian vitamin A pada bayi, dan penyuluhan perawatan kesehatan bayi serta penyuluhan ASI eksklusif, pemberian makanan pendamping ASI (MP ASI) dan lain-lain. ${ }^{15}$ Hanya saja dalam penelitian ini pemberian imunisasi kepada anak dari remaja perempuan tidak sepenuhnya adalah andil dari ibunya. Hal ini disebabkan karena ibu tidak mengetahui tentang jadwal dan fungsi imunisasi bagi bayinya. Hampir seluruh remaja perempuan dalam penelitian ini dibantu oleh orang lain seperti mertua, orang tua, ataupun keluarga yang tinggal bersamanya untuk memberikan saran terkait imunisasi yang diberikan kepada bayi.

Perkawinan usia anak mengakhiri masa remaja anak perempuan, yang seharusnya menjadi masa bagi perkembangan fisik, emosional, dan sosial mereka. Masa remaja ini juga sangat penting bagi mereka karena ini adalah masa dimana mereka dapat mempersiapkan diri untuk memasuki masa dewasa. Perkawinan usia anak seringkali menimbulkan dampak buruk terhadap status kesehatan, pendidikan, ekonomi, keamanan anak permpuan dan anak-anak mereka, serta menimbulkan dampak yang merugikan bagi masyarakat.

Kondisi yang fatal dan mengancam jiwa akan dialami oleh 14,2 juta anak perempuan di seluruh dunia yang menjadi pengantin anak setiap tahunnya selama periode 2011-2020. Perkawinan usia anak menyebabkan kehamilan dan persalinan dini, yang berhubungan dengan angka kematian yang tinggi dan keadaan tidak normal bagi ibu karena tubuh anak perempuan belum sepenuhya matang untuk melahirkan. Anak perempuan usia 10-14 tahun memiliki resiko lima kali lebih besar untuk 
meningal dalam kasus kehamilan dan persalinan usia 20-24 tahun, dan secara global kematian yang disebabkan oleh kehamilan merupakan penyebab utama kematian anak perempuan usia 15-19 tahun. Anak perempuan menghadapi risiko tingkat komplikasi yang terkait dengan persalinan yang jauh lebih tinggi, seperti fistula obstetri, infeksi, pendarahan hebat, anemia dan eklampsia. Terdapat kajian yang menunjukkan bahwa perkawinan usia anak di Indonesia berhubungan dengan buruknya kesehatan reproduksi dan kurangnya kesadaran anak perempuan terhadap risiko persalinan dini.

Penelitian ini diperkuat oleh hasil penelitian yang dilakukan oleh Budi Setyawati, dkk (2013). Hasil penelitiannya menjukkan bahwa wanita yang pernah hamil pada usia dini lebih banyak yang tidak memeriksakan kehamilannya dibandingkan yang menikah cukup usia. Pada wanita yang menikah cukup usia sekitar sepertiganya mendapatkan penyuluhan tentang kesehatan reproduksi, sedangkan pada wanita yang menikah dini hanya seperlimanya, sedangkan pada pertanyaan khusus bagi wanita yang pernah hamil dan melahirkan sejak 2005-2010, didapatkan data bahwa wanita yang mendapatkan informasi tentang tanda bahaya kehamilan $(47,2 \%)$ dibandingkan wanita menikah dini (39,6\%). Hal ini juga dimungkinkan karena rendahnya tingkat pendidikan dan pengetahuan responden termasuk keterbatasan akses memperoleh informasi tersebut.

Selain dampak fisik yang dapat diperoleh oleh remaja perempuan yang menikah diusia dini. Remaja perempuan juga akan mendapati dampak psikis. Sejatinya anak perempuan di bawah umur belum paham benar mengenai hungan seks dan apa tujuannya. Mereka hanya melakukan apa yang diharuskaan pasangan terhadapnya tampa memikirkan hal-hl apa yang melatarbelakangi itu jika sudah demikian, anak akan merasakan penyesalan yang mendalam, dalam hidupnya. Akibat pernikahan dini ini akan menggangu kejiawaan anak sebagai pelaku pernikahan dini. Akibatnya, ia sering murung dan tidak bersemangat. Bahkan ia pun merasa minder untuk bergaul dengan anak-anak seusianya mengingat statusnya sebagai istri.

Hal tersebut memberi gambaran bahwa pengetahuan remaja perempuan tentang kesehatan reproduksi masih kurang. Remaja perempuan yang telah melakukan pernikahan usia dini kurang memahami dampak dari pernikahan dini seperti risiko kehamilan dan persalinan di usia yang masih sangat muda. Pengetahuan yang kurang menyebabkan mereka kurang mengerti manfaat yang diperoleh jika melakukan pemeriksaan kehamilan yang berkualitas. ${ }^{(16)} \mathrm{Hal}$ terkait yang sangat minim pengetahuan pada remaja perempuan adalah kehamilan, bersalin, nifas, dan menyusui. Selain meningkatkan angka kematian ibu dan bayi, pernikahan dini juga menyebabkan beragam masalah kesehan reproduksi. Meningkatnya angka kesakitan dan kematian pada usia remaja salah satunya disebabkan karena rendahnya kunjungan atau pemeriksaan ibu hamil ke tenaga kesehatan. WHO telah menentapkan efektivitas kunjungan ANC yang baik $4 x$ selama kehamilan. ${ }^{15}$ Dari hasil kajian penelitian ini mengindikasikan bahwa setiap kehamilan mempunyai risiko khususnya kehamilan remaja seperti yang terjadi pada remaja perempuan pada penelitian ini ada yang masih merasakan sakit pada jalan lahir, bekas operasi sesar masih sakit, hingga adanya bayi yang mengalami BBLR. Oleh karena itu, pemanfaatan ANC yang teratur akan efektif untuk mencegah hal-hal yang tidak dinginkan pada masa kehamilan.

\section{KESIMPULAN DAN SARAN}

Gambaran status kesehatan remaja perempuan ditinjau dari dua hal yaitu kondisi ibu dan kondisi anak. Pertama, kondisi anak itu diketahui melalui status gizi anak dan imunisasi anak. Status gizi anak diketahui dengan berat badan anak saat dilahirkan. Penelitian ini menunjukkan hasil yaitu yang mengalami berat badan lahir rendah (BBLR) sebanyak 8 orang $(9,9 \%)$, sedangkan yang tidak mengalami BBLR sebanyak 73 orang $(90,1 \%)$.

Selanjutnya, status imunisasi anak, hasil penelitian menunjukkan menunjukkan bahwa yang memberikan imunisasi sebanyak 77 orang $(95,1 \%)$, sedangkan yang tidak memberikan imunisasi sebanyak 4 orang $(4,9 \%)$. Memang hasil ini menunjukkan hal yang baik, tetapi menurut pengakuan remaja perempuan yang sudah menjadi ibu tersebut, pemberian imunisasi tersebut ada bantuan orang ketiga untuk dilaksanakan yaitu ibu remaja perempuan, mertua, atau petugas kesehatan 
di sekitar rumahnya. Kedua, kondisi ibu diketahui melalui kondisi saat hamil, kontrasepsi, gejala anemia, kondisi fisik, kondisi psikis. Untuk kondisi saat hamil, penelitian ini meninjau dari usia pertama hamil yang dianggap berisiko yaitu dibawah usia 16 tahun. Usia $\leq 16$ tahun menjadi usia terbanyak remaja perempuan hamil sebanyak 74 orang $(80,5 \%)$, sedangkan usia $>16$ tahun sebanyak 18 orang $(19,5 \%)$. Pengetahuan remaja perempuan tetang KB bisa mencegah kehamilan. Yang mengetahui sebanyak 78 orang $(77,2 \%)$, sedangkan yang tidak mengetahui sebanyak 23 orang (22,8\%). Gejala anemia yang dirasakan oleh remaja perempuan berdasarkan hasil penelitian menunjukkan bahwa yang mengalami anemia sebanyak 58 orang $(57,4 \%)$, sedangkan yang tidak mengalami sebanyak 43 orang (42,6\%). Kondisi fisik menggunakan diukur melalui indikator Indeks Massa Tubuh (IMT) yang dimiliki oleh remaja perempuan dalam penelitian ini, yaitu berat badan kurang sebanyak 18 orang $(17,8 \%)$, berat badan ideal sebanyak 66 orang $(65,3 \%)$, dan berat badan lebih sebanyak 17 orang $(16,8 \%)$. Terakhir, kondisi psikis yang dialami oleh remaja perempuan. Mengalami depresi dengan kategori, yaitu ringan dan sedang masing-masing sebanyak 11 orang $(10,9 \%)$, sedangkan parah sebanyak 3 orang (3\%). Mengalami kecemasan dengan kategori, yaitu ringan sebanyak 13 orang $(12,9 \%)$, sedang sebanyak 29 orang $(28,7 \%)$, parah sebanyak 12 orang $(11,9 \%)$, bahkan sangat parah sebanyak 6 orang $(5,9 \%)$. Selanjutnya, mengalami stress dengan kategori, yaitu ringan sebanyak 16 orang $(15,8 \%)$, sedang sebanyak 10 orang $(9,9 \%)$, bahkan parah sebanyak 4 orang $(4 \%)$.

\section{DAFTAR PUSTAKA}

1. Candraningrum D. 2016. Pernikahan Anak: Status Anak Perempuan. J Peremp [Internet]. 2016;II(2):8897. Available from: https://www.jurnalperempuan. org/uploads/1/2/2/0/12201443/jp_88-cjp_4_.pdf

2. UNICEF. 2015. Early Marriage, A Harmful Traditional Practise; A Statistical Exploration [Internet]. 2015. Available from: https://www.unicef.org/ publications/index_26024.html

3. National Population and Family Planning Board B, National Statistics Bureau B, Ministry of Health I, International I. Demographic Health Survey (DHS) 2013. Jakarta; 2013.
4. Indonesia KKRI. Riset Kesehatan Dasar (Riskesdas) 2013 [Internet]. Jakarta: Kementerian Kesehatan Republik Indonesia; 2013. 21-40 p. Available from: http://www.depkes.go.id/resources/download/ general/Hasil Riskesdas 2013.pdf

5. UNICEF. Ending Child Marriage: Progress and Prospects [Internet]. 2019. Available from: https:// data.unicef.org/resources/ending-child-marriageprogress-and-prospects/

6. National Statistics Bureau B. The Indonesia Population Census 2015. Jakarta: Badan Pusat Statistik Nasional Republik Indonesia; 2015. 5-7 p.

7. Sarlito Wirawan s. Psikologi Remaja. Revisi I. Jakarta: PT Raja Gravindo Persada; 2011.

8. Nandang M, Ridwan I, R I. Faktor-faktor yang berhubungan dengan Usia Menikah Muda pada Wanita Dewasa Muda di Kelurahan Mekarsari Kota Bandung. J Kesehat Kartika STIKES A Yani. 2017;।(2):59-71.

9. UNESCO. UNESCO Global Partnership for Girls and Woman Education One Year on May 2011-May 2012 [Internet]. 2012. Available from: https://www. globalpartnership.org/results/education-datahighlights

10. UNICEF. Early Marriage Fact Sheet [Internet]. 2018. Available from: https://www.prb.org/childmarriage-fact-sheet/

11. Dwi Rifiani. 2017. Pernikahan Dini dalam Perspektif Hukum Islam. De Jure Jurnal Hukum dan Syariah. 2017;2(3):125-34.

12. Alfiyah. 2018. Pernikahan Dini. Univ Muhammadiyah Malang [Internet]. 2018;I(2):26-31. Available from: http//alfiyah23.student-umm.acc.id

13. Handayani EY. 2014. Faktor-Faktor yang Berhubungan dengan Pernikahan Usia Dini pada Remaja Putri di Kecamatan Tambusai Utara Kabupaten Rokan Hulu. Jurnal Maternity and Neonatal Vol 1 No.5, 2014 hal 200-206

14. Landung J, Thaha R, Abdullah A Z. 2009.Studi Kasus Kebiasaan Pernikahan Usia Dini Pada Masyarakat Kecamatan Sanggalangi Kabupaten Tana Toraja. J Media Kesehat Masy Indones. 2009;5(4):89-94.

15. Kusmiran E. 2011. Reproduksi Remaja dan Wanita. Jakarta: Salemba Media.

16. Ratnaningsih M, Zulkifli A, Hakim B. Pengaruh metode simulasi permainan dan brainstorming terhadap pengetahuan dan sikap Pengurus PIK-R SMA tentang kesehatan reproduksi remaja di kota makassar [Internet]. Universitas Hasanuddin; 2012. Available from: http://repository.unhas.ac.id/ bitstream/handle/123456789/6984/9. muliani. docx?sequence $=1$ 